\title{
Looking for sustainable solutions in salmon aquaculture
}

\author{
Jennifer Bailey \\ Department of Sociology and Political Science, NTNU, jennifer.bailey@svt.ntnu.no
}

Sustainable development poses highly complex issues for those who attempt to implement it. Using the Brundtland Commission's definition of sustainable development as a vantage point, this article discusses the issues posed by the production of one kind of food, farmed Atlantic salmon, as a means of illustrating the complexity, interconnectedness and highdata requirements involved in assessing whether a given industry is sustainable. These issues are explored using the three commonly accepted aspects of sustainability - its environmental, social and economic aspects - and the dilemmas posed by the need to make the trade-offs necessary among these. It concludes by arguing that decisions of this complexity require complex and multiple decision-making structures and suggests four that are essential for the task.

Key words: sustainability, sustainable development, aquaculture, salmon aquaculture

\section{Introduction}

The world's population is growing, living standards for many are improving and demand for food is increasing. At the same time, climate change is making agricultural production less predictable, biofuels compete with food production for agricultural output, the expansion of meat production is putting strain on the great rainforests and the supply of fish from capture fisheries is holding steady or even declining. How can this demand for food be met in a sustainable fashion?

The food that humans consume now comes overwhelmingly from land-based sources, while half of the planet's primary production - the generation of organic material from sunlight - occurs in the vast oceans (Olsen 2011). Yet ocean capture fisheries have already stagnated at current levels. Many think that aquaculture, especially marine aquaculture, will provide an important part of future food requirements. Marine-based aquaculture is already a substantial activity, but current trends require its expansion many times over if we are to meet future demand. Collectively, we have already begun to go down this road, but our journey has only just started. We should think carefully about where we are going before structures become fully entrenched and hard to change.

This article discusses one source of food, the farming of Atlantic salmon, as a means of illustrating the complexity and interconnectedness of the systems in which we exist, the difficulty of the choices we have to make and the high-data requirements required to 
make them. The analysis here draws upon the experiences of farmed Atlantic salmon in Norway and in Chile: the two leading producers of this species. These issues are explored by considering three of the commonly accepted aspects of sustainability - its environmental, social and economic aspects - and the trade-offs among these. It concludes by arguing that achieving something as complex as sustainability requires complex and multiple decision-making structures and suggests four that are essential for the task.

\section{What is sustainability?}

The most common definition of sustainability is that of the Brundtland Commission report (International Institute for Sustainable Development 2013). It defines sustainable development as «development which meets the needs of current generations without compromising the ability of future generations to meet their own needs» (World Commission on Environment and Development 1987: chapter 2, point 1). This definition, however, is frequently employed without reference to what these needs might be. The Commission itself provides some guidance. It affords «overriding» priority to meeting the «essential needs of the world's poor», specifically mentioning food, clothing, shelter and jobs (chapter 2, points 1 and 4), while it also states that «sustainable development requires $[\ldots]$ extending to all the opportunity to satisfy their aspirations for a better life» (chapter 2, point 4 ) and observes that "perceived needs are socially and culturally determined» (chapter 2, point 5).

The overall approach of the Commission highlighted the necessity to make choices between development models and clearly indicated that multiple dimensions of human social systems as well as those of natural systems would have to be taken into account for development to be sustainable in the long run. By using the concept of «needs», the Commission posited a criterion for evaluating the options. However, by including the ideas of satisfying aspirations and that needs are socially and culturally determined, the Commission left a great deal of room for interpretation as to what a legitimate «need» might be. We would have to make conscious trade-offs among dimensions while armed only with a rudimentary choice criterion. It also remained unclear as to who should make these choices and how.

The Brundtland Commission report sparked an intense debate about what sustainability constituted (Lélé 1991). As the debate raged on, attempts to manage natural renewable resources were running into difficulties. The failure of traditional approaches in managing fisheries led to the broad embrace of a holistic, ecosystem approach to management. Viewing the marine environment as an intricate system composed of complex subsystems harmonized with the thinking embodied in the emerging concept of Integrated Coastal Zone Management (ICZM), which views the natural systems in the waters and lands along the coast and the multiple human activities that occur in both as intricately interconnected (Forrest 2006: 208). ICZM in turn adheres to the increasingly accepted view that human and natural systems are in turn subsystems within coupled socioecological systems (SES) (Gelcich et al. 2010: 16794; Ostrom 2007). Trying to manage any 
system is difficult and requires an enormous amount of information. No single element can be managed in isolation from others and causal connections are complicated, hard to plot out and often surprising. The SES, joining highly complex natural and human systems, which are in turn composed of multiple subsystems, is especially complex and opaque and demands data that are frequently lacking. This has meant that even as we struggle with finding the best ethical basis for our choices, we have lost confidence in being able to predict what the outcome of even the best intentioned choices will be.

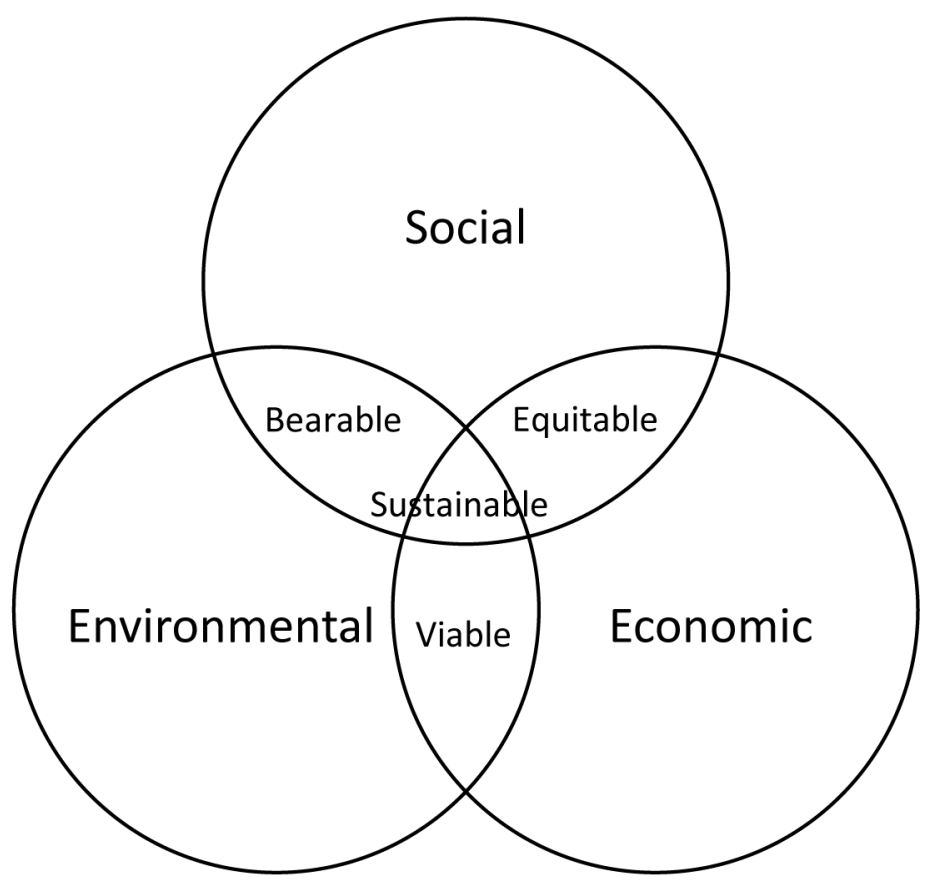

Figure 1 Derived from the graphic and text created by Barbier (1987)

The SES is a good representation of the world in which we live but its very complexity makes it difficult to know where to start when evaluating the sustainability of any given human activity. In such cases, it is customary to begin with a simplified model. Here, we turn to the popular sustainability Venn diagram with its social, environmental and economic components. First introduced, perhaps, in 1987 by Barbier, the diagram reflects the long-running tendency to discuss sustainability along these dimensions. The triad was picked up by the Commission and remains a standard approach to the concept (including the business-oriented «triple bottom line») (Lozano 2008: 237; Norman \& MacDonald 2004; Vanderbilt University 2014; Giddings, Hopwood \& O’Brien 2002). The inclusion of the «equitable» 
criterion in the diagram incorporates the Brundtland Commission's assumption that only equitable choices can endure over the long run and the diagram provides a clear visual reminder that we must choose among various options. Here, it provides a simple organizing principle for a brief examination of the difficult choices offered by a single industry. The use of this simplified model is also illustrative of the problem, as it yields a highly complex set of issues to consider even as it fails to replicate the full intricacy of the SES (Giddings, Hopwood \& O’Brien 2002: 189).

While this simplified diagram leaves us with many conceptual difficulties (see for example Giddings, Hopwood \& O'Brien 2002: 188-189), this article can take up only one of these: level of analysis. What is it that must be sustainable? Do we mean that each and every firm, community or country must be sustainable in and of itself, or is sustainability imagined as an aggregate situation? Aggregate solutions may well be found at the expense of some individual firms, industries, communities or even countries, while problems solved at the level of local ecosystems may export problems to other or to higher-level systems. We will undoubtedly have to choose among different socio-economic-environmental package solutions with very different implications that vary by socio-ecological setting.

\section{Is aquaculture sustainable?}

Marine Harvest, a major aquaculture company, argues that «fish farming is an important part of the solution on how to feed a growing world population» (Marine Harvest 2011). In doing so, the company claims high moral ground by linking its business to what seems to be a basic need: food. The need for farmed fish does seem compelling. Marine and fresh water capture fisheries provide a great many fish to the table. Growth in both has leveled off over the last few decades, however, with catches fluctuating around the 11.5 million tons of fresh fish and 78.9 million ton of marine fish reported for 2011 (FAO 2012: 3). No further growth is anticipated. Aquaculture - fresh, marine, and brackish (62\%, $30 \%$ and $7.9 \%$ of world production respectively) - now accounts for the increases in aggregate fish supply (from an average of $11.5 \mathrm{~kg}$ per person in the $1960 \mathrm{~s}$ to about $15.4 \mathrm{~kg}$ in 2009). Its total production is beginning to rival that of the capture fisheries, contributing a total of 63.6 million tons, compared to the 90.4 million tons landed in the capture fisheries (FAO 2012: 5, 34). The FAO estimates that nearly 50 percent of all foodfish are now farmed and this proportion is expected to increase in the future (FAO 2014a).

However, the many kinds of aquaculture vary with respect to the trade-offs they represent among the three dimensions of sustainability: they are different sorts of enterprises, use different and varying amounts of resources and meet different sets of needs and preferences. The intense debate about the feed requirements of various farmed species serves here as an entry point to the discussion. Not all farmed aquatic species are fed by those who raise them. The large category of freshwater aquaculture is dominated by carp, about a third of which are non-fed filter feeders. The carp that are fed are usually fed locally produced low-protein feeds that escape accounting in the international production statistics. 
Marine aquaculture is dominated by lower trophic organisms, meaning that these are lower on the food web: molluscs (oysters, mussels, clams, scallops and other bivalve species) account for 75 percent of production. Molluscs are generally non-fed. While the absolute quantity of non-fed production is increasing, its percentage of total aquaculture production is decreasing, from just over 50 percent in 1980 to about 33 percent in 2010 (FAO 2012: 5, 29, 34-36). Marine Harvest primarily cultivates Atlantic salmon, a carnivorous species that requires commercially prepared, high-protein feed that draws upon resources that are used in the production of other foods (Tacon, Hasan \& Metian 2011: 8 ). Is the cultivation of Atlantic salmon a part of the solution - or a part of the problem? This question will be examined using the social, economic and environmental aspects of sustainability and examining the trade-offs among these.

\section{Farmed Atlantic salmon and sustainability}

The farming of Atlantic salmon has increased tremendously in the last decade. Global salmon production - a category overwhelmingly dominated by Atlantic salmon - has had an average growth rate of 5.5 percent per year over the last decade. In 2011, about 1.42 million tons of farmed Atlantic salmon were produced.

\section{Environmental issues}

Salmon aquaculture carries with it four broad categories of potential direct threats to ecosystems at different levels. The first three categories primarily affect local ecosystems: 1) disease and parasites; 2) pollution issues (chemicals, antibiotics, nutrients released into the water through feed and fish feces) and 3) genetic and other threats to wild salmon and other local species populations. The fourth, the use and the transfer of protein and other nutrients/substances from one area to another via fish feed, introduces impacts on other, including higher, ecosystems.

The presence of farmed salmon can cultivate and spread diseases, such as infectious salmon anemia (ISA) and pancreas disease (PD), and parasites, such as the worm Gyrodactylus salaris and salmon lice (Lepeotheirus salaris) that affect both the farmed salmon and various wild stock (Evans 2006; Krkošek et al. 2011). The extensive use of antibiotics can result in the further degeneration in the usefulness of this important defense against disease. The addition of nutrients (originating in both feed and fish feces) can produce eutrophication (the stimulation of organic, especially primary, production) resulting in algae blooms and, in some situations, hypoxic (reduced oxygen) and anoxic (depleted oxygen) local waters. The feeding of fish contained in pens located in the seas can alter the behavior, health and feeding patterns of wild stock of various species that take advantage of this easily available nourishment. Farmed salmon that escape from pens can affect wild salmon by mingling genetically with wild stock and by competing with them for food (Fleming et al. 2000; Jonsson \& Jonsson 2006; Thorstad et al. 2008: 6). It is estimated that 14-36 percent of the Atlantic salmon spawning population of the average Norwegian salmon rivers is made up of farmed salmon, and that, for some rivers, that figure may be 
as high as 80 percent (Liu, Olaussen \& Skonhoft 2011: 451). Wild Atlantic salmon may be a particularly vulnerable species because their lives revolve around specific rivers as they journey through several environments and jurisdictions over the course of their lives. Once they disappear from a particular river it is difficult to bring them back.

The lure of genetically modified (GM) salmon poses a potential future threat to wild stocks. All selective breeding results in the genetic modification of the species, but GM organisms have been changed in a way that does not occur naturally (World Health Organization 2014). US-based AquaBounty has developed a GM salmon, AquAdvantage ${ }^{\circledast}$ salmon (AAS), that it claims grows much more rapidly than its wild counterpart (AquaBounty 2013). While they may use feed more efficiently, which might lessen the burden of the industry at the aggregate ecological level, escaped AAS are likely to pose a threat to local wild salmon populations: escapees could either mix with them genetically or outcompete them for food (Fisheries and Oceans Canada 2013: 14-16). Canada has authorized AquaBounty to produce the eggs of its AAS in Canada for commercial use in Panama (AquaBounty 2013). This may protect Canada's stocks but raises questions about the ethics of exporting such species to other ecosystems and about impacts on human health.

In some contexts, Atlantic salmon are an alien or «invasive species». Chile, the second largest producer of Atlantic salmon in the world (Marine Harvest 2012: 13) faces the Pacific rather than the Atlantic Ocean, and Atlantic salmon are not a native species. The impact upon local species in Chile is understudied and largely not known but benthic bio-diversity loss has been reported in some areas (Buschmann et al. 2006). There are scattered reports that escapees have survived in these alien waters (Soto, Hara \& Moreno 2001) and have interacted with native fish communities (Buschmann et al. 2006: 1342), although the long-term impacts are unclear (Thorstad et al. 2008: 3). There is a chance that the globalized character of the industry accounts for the spread of the ISA disease to Chile (Center for Food Security and Public Health \& Institute for International Cooperation in Animal Biologics 2010); human activity also seems to have spread disease and parasites to new areas (Evans 2006). Chile also presents another, related issue: the Los Lagos region, which has been the center of the salmon industry, is characterized by isolated, glacier-formed fresh water lakes that have developed many unique species; the use of these for the cultivation of smolt endangers fragile freshwater ecosystems that have been classified as priority areas for conservation (Iriarte, Gonzales \& Nahuelhual 2010: 463; León-Muñoz et al. 2007: 21).

However, the direct environmental threats posed by the cultivation of Atlantic salmon are only part of the story. A more complete assessment would require evaluating the environmental impact of the resources utilized in the production of salmon as well as those associated with its transportation and consumption. Life Cycle Analysis (LCA) is one approach that attempts to do just this. Such an analysis can reveal the less obvious impacts of a given product, but it is a complex analysis that requires a good deal of information. A lighter version of LCA, Systems Analysis, highlights the industry's impact on the global ecosystem through the $\mathrm{CO}_{2}$ emissions resulting from the production of feed (Ellingsen, Olaussen \& Utne 2009). The industry may also transform settlement patterns and infra- 
structure in the countryside, creating a cascading effect on coastal and inland ecosystems. For example, the aquaculture industry in Chile is poised to expand into the southern part of the country where there is scant population and, accordingly, little infrastructure; facilities for workers and infrastructure of the production and transportation for the product will have to be introduced into new areas.

This brings us back to the issues connected to the feed required by Atlantic salmon. Since it is a carnivorous species, its feed necessarily contains fishmeal and fish oil. Plans to increase the production of Atlantic salmon may well run up against a shortage of those ingredients which have a variety of uses and are already in short supply. This, as noted, introduces issues that go far beyond the location of salmon cages. Fishmeal and fish oil are produced largely from the reduction of low-value, high-volume fisheries such as the Peruvian anchovy. Higher demand for fishmeal and fish oil increases their price and makes it less likely that these fish or their products will benefit low-income consumers; it also maintains or increases pressure on wild stocks that are already fully exploited and highly unstable (NOAA 2014). Feeding wild fish to farmed carnivorous Atlantic salmon is inefficient in the sense that there is a large net loss of food energy as trophic level increases (Olsen 2011; Pinto \& Furce 2006). The exponential increase in production of Atlantic salmon could place a larger drain on aggregate marine resources than the total wild stock ever did. The farming of Atlantic salmon involves the importation of feed manufactured from species that flourish far away from the natural range of Atlantic salmon. This means that protein and other nutrients and the chemicals used in the feed (ranging from soy products to phosphates) are shifted into new areas, with the potential to alter existing ecosystems (Hamilton 2013).

The picture is still more complicated, however. Many of these problems are recognized and addressed by both governments and industry to greater and lesser degrees. In Norway, a great deal of research is going into the construction of better cages to prevent escapes. Mapping of coastal zones is establishing where cages can be placed to minimize the threat of eutrophication, and regulations place limits on the density of cages in a given area, the density allowed within cages (to reduce the outbreak and spread of disease) and distancing these from salmon rivers (to reduce the direct threats to wild stock). Researchers are investigating whether facilities can be placed farther offshore, reducing pollution impacts by insuring the dispersal and degrading of organic components. Feed can be sparingly and efficiently dispensed (reducing impacts on other species and the sea floor), fish are routinely vaccinated (reducing or eliminating the use of antibiotics administered to caged fish), and multi-trophic aquaculture is being explored as a way of utilizing the nutrients released into the environment via both feed and feces (see, for example the Norwegian Research Council financed EXPLOIT project). Sterilization of farmed salmon is being explored as a way of reducing impact on wild stock. The controversial GM salmon at least raises the possibility of engineering fish that use feed more efficiently and that resist illness and parasites. For the record, however, Norway and many others do not use GM salmon, and the dominant company Marine Harvest opposes it (Norwegian Seafood Federation \& Norwegian Seafood Council 2010; Fish and Information Services 2013). 
Through these initiatives, aquaculture may be environmentally viable, especially at the level of localities and with reference specific wild stocks, but institutional context has much to say about whether measures that ensure best practice will be implemented. The industry in Chile has not come so far. Its aquaculture cages have been packed more closely together, fish densities in the cages have been higher, antibiotic use has been high, less information is available for placing cage sites in optimal conditions, there are no protected areas and the industry uses sensitive freshwater lakes for smolt production. In both Norway and Chile, escaped salmon remain a problem (Fiskeridirektoratet 2013; LeónMuñoz et al. 2007: 7-8; Marine Harvest 2009: 48).

Measures are also being taken to address the major feed issues. Salmon feed today incorporates a lower percentage of fishmeal and fish oil than it ever has. According to Olsen (2011), these changes in feed have already reduced the trophic level of farmed salmon $(+3)$ to below that of wild salmon (4). Still, the alternatives to fishmeal and fish oil are not without issues of their own. The manufacture of feed now increasingly draws upon agricultural products such as soy, shifting competition for fisheries resources to competition to agricultural products. However, while Atlantic salmon can get protein from non-marine sources, it requires highly unsaturated fatty acids (HUFAs), which it cannot obtain or synthesize from agricultural products. For now, there are limits to reducing the fishmeal and fish oil components. Research into the use in feed of organisms from lower trophic level marine fauna, such as copepods (tiny crustaceans), is promising but still some time off (Olsen 2011: 188).

The amount of knowledge required for a comprehensive picture is staggering and only a few aspects have been addressed here. Gaining a comprehensive understanding of the environmental impact of salmon aquaculture could lead to analyses of infinite regression. In addition, the knowledge is moving target, since changes in the industry and in the natural systems in which it operates are continuous.

\section{Economic sustainability}

Is salmon aquaculture sustainable economically? This is a huge question and only two points can be touched upon here. First, is the industry actually profitable? Second, what kind of industry or firm is sustainable?

Figures for both the total quantity and value of Atlantic salmon aquaculture have steadily increased over recent decades despite fluctuations. The scramble to solve environmental problems connected to the industry is an indication of broad interest in expanding this industry. Current expansion and plans for future expansion also suggest that the industry as a whole is having no difficulty attracting investment, meaning that it is an attractive investment compared to the alternatives (Marine Harvest 2012: 15).

At the national level, the industry in Norway is apparently doing well, with the value of total production rising from about 757 million dollars in 1990 to almost 5 billion dollars in 2011 (FAO 2014b). Average results at the company level in Norway show a steady increase since 2008 (although this dipped in 2012) (Fiskeridirektoratet 2014). FAO statistics show a similar vitality in the Chilean industry until it was devastated by the 2007 ISA 
outbreak. The continued attractiveness of the Chilean industry is illustrated by the recent resurgence of the industry there.

The evolution of the industry, however, suggests that not just any kind of firm is competitive, or sustainable, over the longer run. Aquaculture got its impetus in Norway in the 1970 s as a government strategy to replace the jobs being lost to the decline and transformation of the fishing industry. The first ventures were relatively small enterprises run by local entrepreneurs, and these quickly multiplied. However, after disruption by disease, the sector consolidated and is now dominated by large, international and vertically organized firms (Liu, Olaussen \& Skonhoft 2011; Phyne 2010). Although smaller operations continue to exist, large companies are consistently relatively more profitable than small or medium-sized enterprises (Fiskeridirektoratet 2014). The global production of farmed salmon is also dominated by large companies, and particularly by Norwegian companies. Marine Harvest is the largest single salmon-farming company in the world, holding one quarter of the volume in Norway and about one-third of the production in North America and UK (Marine Harvest 2012). Marine Harvest is also the single largest producer in Chile. The need to sell its product quickly once produced, the sensitivity of the industry to disease and the fluctuations of the international market may favor large enterprises (Marine Harvest 2012: 18).

The Chilean industry was born in the aftermath of the most severe economic downturn in the country since the 1930s which brought with it social unrest. This was also the time of the Pinochet dictatorship which promoted neo-liberal economic policies and repressed labor unions. The industry was driven by «old capital» diversifying from other sectors. Chilean policy favored quick growth, few regulations and «flexibilisation» of the work force (Barton \& Fløysand 2010:4). Salmon farming consequently exploded in Chile and its profitability became legendary. It was a part of the Chilean «economic miracle» that transformed the country. The industry outperformed other key export industries that played an important role in the Chilean miracle and, in 2008, the value of salmon exports exceed USD $\$ 2.4$ billion. The industry planned to double its production by 2015 (Arengo, Diaz, Ridler \& Hersoug 2010: 16-17). The industry in Chile has been concentrated in the Los Lagos area of Chile, particularly around Puerto Montt and Chiloé and brought jobs to this chronically depressed area. The industry has had its ups and downs, however. A contraction in the industry in 1990s led to the infusion of foreign capital as Norwegian companies such as Nutreco/Marine Harvest took over Chilean firms in distress (Phyne 2010: 169). The larger crises that began in 2007 intensified the consolidation of the industry (Arengo, Diaz, Ridler \& Hersoug 2010: 20; Marine Harvest 2012: 24). It is today characterized by «high vertical integration, economic concentration and significant foreign investment» (Phyne 2010: 169). The industry has today returned to profitability (Bustos 2010: 160).

\section{Social sustainability}

What is social sustainability? In a world of vague definitions, this is perhaps one of the least well defined. Here, it is defined as the maintenance of a community as a coherent, 
functioning unit. The idea of «community» can of course be thought of as operating at several analytically distinct levels: at the level of individual municipalities, or at regional, national and international levels. The discussion here can only touch upon these in a superficial way.

Defining social sustainability as is done here revives a concept from sociology that has fallen out of fashion lately: structural functionalism. Its attraction is the idea that societies should be viewed as systems, with constituent elements and subsystems performing roles necessary to system survival. This harmonizes with the growing popularity of the SES. While there are issues with the structuralist-functionalist approach, as discussed below, it does provide a way of examining the challenges that an industry like aquaculture might present. There is only space here, however, to take on a few of the industry's roles in the social system: supplying jobs that provide sustenance to a community and supporting cultures that provide meaning.

The most basic question is whether the industry provides jobs - one of the Brundtland Commission's basic needs. However, the question is not just how many jobs but also what kinds of jobs and the implications these have for the greater community. Figures from the Ministry of Fisheries and Coastal Affairs (2013) show that the aquaculture of Atlantic salmon, rainbow trout and trout does provide jobs all along the Norwegian coast, from Rogaland in the south to Finnmark in the north. Even so, the number of direct jobs created is not large, nor is the number increasing. In 2012, the industry directly provided about 4,605 jobs nationwide, about the same as in 1994 (Hersoug \& Johnsen 2012: 271; SSB 2014). In comparison, the number of fulltime fishermen in Norway declined by almost 7,000 between 1995 and 2011 (MFCA 2013: 9). The industry however, claims that it is today «responsible» for 22,000 jobs throughout the country (Norwegian Seafood Federation \& Norwegian Seafood Council 2011: 3).

Yet the benefits of the industry are distributed unequally. Jobs in the production of feed and equipment, and in transportation and consulting are important, but they are clustered in the larger, more central communities, while the cage sites are much more widely dispersed (Hersoug \& Johnsen 2012: 271). Additional jobs are generated by the substantial research and development funded by the industry and the states, but these too are only rarely of direct benefit to smaller, more marginal communities. The relatively low number of jobs is directly associated with the consolidation of the industry. While 70 companies produced 80 percent of Norway's Atlantic salmon in 1997, that number had decreased to 22 by 2012 (Marine Harvest 2012: 25); the number of facilities for slaughtering the fish also decreased from 38 in 1999 to 22 in 2009. The processing of salmon and trout is steadily more automated and robotized and also tends to be located in more central areas. Many smaller communities receive little in the way of tax on the use of their area for salmon cages (Hersoug \& Johnsen 2012: 273). At the same time, the process of determining where an aquaculture cage can be placed incurs costs and also stirs up conflicts among local groups, such as fishermen, the tourism industry, owners of holiday cabins and those who fish salmon in adjacent rivers. Many small localities derive few benefits from the industry and an increasing number of them are opposing the further expansion of the industry in their area (Hersoug \& Johnsen 2012: 271-274). 
There are some exceptions. The smaller mid-Norwegian communities of Frøya and Hitra are flourishing. In part thanks to «local patriots», such as the owner of Salmar, Gustav Witzøe, these small communities have managed to hold onto fish processing facilities and supporting services and industry. It is therefore interesting to note that this success brings with it its own issues. Local employers find it difficult to find native Norwegians to fill processing and other lower-skill jobs. These are instead increasingly taken by immigrant labor, a factor that is transforming the culture of these communities (Tiller et al. 2013).

At the level of Norway as a national community, aquaculture undoubtedly does yield important returns. The seafood sector as a whole provided 5.9 percent of all Norwegian exports; farmed salmon accounted for roughly half of this (MFCA 2013: 5, 27). The Norwegian authorities are encouraging investment in aquaculture and the marine sector more broadly, anticipating the day when revenues from oil and gas decline.

Chile was less developed than Norway was in the 1980s when the industry was born, ranking $40^{\text {th }}$ in the Human Development Index compared to Norway's $6^{\text {th }}$ place. This situation and the economic downturn meant that job creation was even more important in Chile than in Norway. The industry created an economic boom in the chronically economically depressed region of Los Lagos. It is estimated that before the 2007 crisis the industry provided over 50,000 direct and indirect jobs in both Los Lagos and Aysén, making it the export industry that generated the most direct jobs and second in the production of indirect jobs (Arengo, Diaz, Ridler \& Hersoug 2010: 25-26). As with many booms, however, there were also downsides. The industry gained a reputation for low wages, long hours and unsafe and poor working conditions. In addition, only little of the wealth created in the region has actually remained there: it flowed instead to Santiago (Bustos 2010: 161, 172). Many cage sites and facilities were located far from population centers, requiring workers to spend time away from home. The region was hit hard when the industry was impacted. As a result of the 2007 crisis, many lost their jobs: Marine Harvest laid off 1,699 workers, or 68 percent of its workforce (Marine Harvest 2009: 34). Perhaps 20,000 jobs were lost in Los Lagos alone (Arengo, Diaz, Ridler \& Hersoug 2010: 15).

The industry brings cultural issues for both Chile and Norway. In Chile's Los Lagos region, the industry led to a transformation of the «social landscape». For many, receiving a monthly wage was a new experience and brought with it a shift in lifestyle and consumption patterns. Younger people were attracted to the industry, leaving more traditional, communal work behind. Family and gender relations were changed and old social networks interrupted (Bustos 2010: 172). The difference was particularly marked in Chiloé, an island with a distinctive history and culture. It brought changes to Norway, too. The aquaculture industry is less dependent on the vagaries of natural conditions than are, for example, fisheries. Indeed, that is one of its attractions: it provides a steady, predictable supply of fish for processing plants and markets. Raising farmed fish is very different than fishing, however, valuing a different set of skills, implying a different set of social relations in the community and within the home and producing different rhythms of work. The transition to aquaculture is a part of the general transition of Norway away from primary production. Finally, as mentioned above, in some cases, immigrants have arrived to take up jobs in the processing sectors especially, an element transforming local communities. 
A closely related issue is the fate of other industries in areas dedicated to salmon aquaculture. The industry draws labor from other activities, the areas dedicated to cages close it to other uses, the presence of aquaculture sites may be aesthetically displeasing to residents and tourists alike, and escaped salmon can impact local industries. In Norway, the presence of farmed salmon in rivers decreases the attractiveness of the river as a destination for sports fishing. Commercial fishermen are denied access to areas once open to fishing. Owners of second homes decry the visual pollution and local entrepreneurs worry that the presence of facilities may damage the Norwegian scenery that is the foundation of the Norwegian tourist industry (Tiller, Brekken \& Bailey 2012; Norwegian Ministry of Trade and Industry 2012: 55). In Chile, as mentioned above, traditional communal economic activities are declining and the use of lakes for the freshwater phase for salmon has led to conflict with other users (Barton 1997: 318). Conflicts have also emerged between artisanal fishermen and operators of aquaculture sites. These fishermen complain that the industry is damaging their fishing. They are proponents of the legalization of salmon fishing since they are increasingly catching escaped farmed fish. This is opposed by aquaculture concerns (Soto, Hara \& Moreno 2001: 1761). Finally, the Mapuche Indians of the region have denounced the salmon industry for blocking their access to the sea, endangering regional biodiversity in lakes, disrupting alternative development processes and violating the rights of native peoples (ECOCEANOS 2013; Mapuche Documentation Center 2007).

\section{Choices and trade-offs}

Salmon farming, therefore, presents a mixed picture. The following further explores some of the trade-offs and choices the industry requires, using the Venn diagram as a guide. Both conceptually and in practice, however, these issues prove hard to separate.

\section{Environmental-economic trade-offs}

Solutions here have to be viable for the entire socio-ecological system. There are limits to what any system can tolerate before it collapses, but different ecological and human systems tolerate varying degrees of stress. Also, it is not simply a choice between one systemic state and collapse: stress changes the system before it brings on collapse. How much stress, then, should we allow to be exerted on the socio-ecological system?

Atlantic salmon are in general in decline around the North Atlantic for a variety of reasons; the farming of salmon is but one of these. It is not certain that stopping all salmon farming will make a dramatic difference (Windsor, Hutchenson, Hansen \& Redden 2012). A variety of economic activities is threatening the delicate ecosystems of Chilean lakes and overfishing is as much a problem for local marine species as salmon farming is. How much additional damage does aquaculture really cause?

Salmon aquaculture clearly impacts wild species. However, farmed salmon convert feed to growth more efficiently than do wild salmon - or cattle, pigs or foul, for that mat- 
ter (Norwegian Seafood Federation \& Norwegian Seafood Council 2011: 11). The use of copepods for salmon feed is very promising: the size of the biomass is huge and much of it is currently lost to the food system. However, these creatures are also vital to the much larger marine food web. Humans do not have a good record in the sustainable harvesting of ocean resources: Is it wise to start drawing upon these species?

Aquaculture firms, of course, exist within a competitive environment in which only the fittest firms survive. Small industries may be more ecologically friendly but in the current context they do not seem to be particularly competitive. In addition, a highly capitalized and technological industry may use many scarce resources more effectively providing a net saving at the aggregate level even as it threatens environmental problems at the local level.

Of course, whether salmon aquaculture is a good choice also depends on the alternatives. Other sources of protein might not be a better choice, but cultivating lower trophic species might be. In addition, assessing the stress aquaculture places on ecological systems is complex because it is only one of many human activities that impact these. Even the pristine areas of far southern Chile are not untouched; the question is what additional impact it will have and whether that is better or worse than other activities (Bustos 2010: 142). In addition, while extending aquaculture to these regions reduces the cultural or aesthetic value that a theoretically «pristine» environment holds, «untouched» natural systems can support fewer humans than can manipulated ones. For example, the catch of wild Atlantic salmon in the North Atlantic peaked in the 1970s at about 12000 tons. In 2011, the production of farmed Atlantic salmon was 1.42 million (Marine Harvest 2012: 8; Windsor, Hutchinson, Hansen \& Redden 2012: 1).

\section{Social-economic trade-offs}

The salmon farming industry gives rise to innumerable questions about equity. Salmon aquaculture is a highly profitable activity, and it produces remarkable amounts of healthy food at prices far lower than wild salmon used to fetch. However, the dynamics of the global industry work to promote consolidation of the industry - and its profits - into the hands of relatively few companies. These compete with other industries, frequently pitting large corporations against smaller, local actors. The industry transforms the landscape and modernizes society: it can bring jobs to depressed areas but also spreads wealth unequally and forces changes in local customs and work even for those who do not choose to work in the industry. Developing the technological fixes to solve environmental problems requires investment in research and technology, making the industry viable only for the relatively wealthy few who can afford it. This investment is in any case directed towards a higher trophic species that benefits relatively wealthy consumers, owners and countries rather than towards the species that most of the world produces and eats. Salmon farming creates demand for fishmeal and fish oil, maintaining pressure on industrial fishes, but turns out protein-rich food more efficiently than do other industries which also use these. Finally, both Chile and Norway are uniquely endowed with 
conditions that permit the raising of salmon, an economic competitive advantage, but using these can impact people beyond their boundaries.

\section{Environmental-social trade-offs}

What solutions are bearable for both human and natural systems? This returns us to the issue of stress on systems addressed above. It is instructive here to recall the reasons why the structural-functionalist approach is no longer trendy in sociology (and political science) while the systems approach generally gains in popularity. The approach came under criticism for its implicitly static understanding of systems (among other reasons). However, change is constant in all systems, natural and human alike, and stress is a source of change: this makes it hard to know where we stand and how to choose.

Exactly what stresses natural systems can tolerate is for the most part not known. The preceding has outlined the sources of stress that salmon aquaculture may pose for natural systems at various levels but it remains unclear just how great the cumulative stress on specific systems actually is and the impact this is having on them. The difficulty in calculating how much stress a given system can endure in turn makes it difficult to calculate the risks to natural systems posed by specific industry configurations.

The structural functionalist approach does however prompt us to ask what impact salmon aquaculture has on essential social system functions. Here again we find few clear answers, because there are many systems, these exist at different levels and because there are trade-offs among functions. The provision of jobs can clash with the maintenance of tradition and systems of meaning that breathe life into local communities (culture). The loss of Mapuche land and rights may be the price Chile must pay for economic development that benefits many other Chileans. The flourishing of the salmon business in today's competitive market benefits Norway as a country and successful entrepreneurs although not necessarily local Norwegian communities or the Chilean laborers squeezed by the need to compete with the Norwegian products. An industry that flourishes at the national level may bring with it unequal returns at international, regional or local levels. The introduction of new industries and the destruction of old ones destroys the trust and social capital required to make local communities function coherently (Putnam 1993) even while creating more viable national economies.

\section{By way of a conclusion: Decision-making and sustainably}

It is the role of political systems to provide mechanisms for making conscious choices among alternatives for a given community. As yet, these do not exist at the international level, and they do not always function well at the national level. Even where they do, it is difficult to make intelligent decisions about the complex issues. But the salmon aquaculture case suggests that some important decision-making structures do exist, that they are nudging the industry in what looks like a more sustainable direction and that we must identify these and their key characteristics and nurture both. 
First, democratic systems at the national level have been important (Phyne 2010). The Chilean context of dictatorship, repression of labor and gradual transition to democracy worked to make the salmon industry immune to criticism - particularly with respect to what impact the industry was having on the environment (Barton \& Fløysand 2010: 5). The ability of local people to voice concerns about the environment and their living standards has been an indicator as to the progress of this transition. Norway is not only highly democratic, it also has adopted a high environmental standard as a core goal and has a uniquely close relationship with environmental groups (Dryzek, Downes, Scholsberg \& Hernes 2003). Still, democracies must also be effective as states. In Norway the likelihood that the many regulations guiding the industry will be followed is high; while many in Chile doubt that the state has the ability or will to enforce regulations there.

Second, civil society has become the locus of serious negotiations among key stakeholders. The most prominent example of this is the WWF-instituted series of initiatives known as the "aquaculture dialogues». Starting in 2004, the WWF (World Wide Fund for Nature) held a series of eight roundtables that brought NGOs, scientists and other key stakeholders together to discuss issues that concern various aquaculture industries. This has resulted in the development of production standards that may one day lead to a certification process similar to that offered by the Marine Stewardship Council for capture fisheries. The mechanism allowed for the circulation and exchange of local and scientific knowledge, provided a transparent procedure that enhanced trust, gave participants a sense of ownership of decisions and helped establish common ground with respect to values.

Third, and related to the above, there is the market, which provides a different way of making choices. WWF and other NGOs have worked to influence consumer choice, thereby influencing key retail companies such as, for example, the US retailers WalMart and Whole Foods. Both corporations now highlight their dedication to standards that have originated with NGOs; the standards incorporate both environmental and social aspects (Walmart 2014; Whole Foods 2014). The market also impacts producers because poor practices can lead to huge economic losses and the exclusion of the product by health authorities and can damage the firm's reputation.

Fourth, a network of international organizations and agreements has emerged that develop and embrace norms and values that promote sustainability. International agreements that support sustainability, such as the Convention on Biodiversity, non-binding actions plans such as Agenda 21, codes of conduct such as the FAO's code of conduct for aquaculture and the development of principles such as the precautionary principle, are all the product of complex negotiations among states. Many of these incorporate social, environmental and economic sustainability goals, providing avenues for input by regulation authorities, scientists and stakeholders.

Together, these four fora bring together an enormous number of actors who continually negotiate about values, needs and preferences. Collectively they provide information about the economic, social and environmental aspects of sustainability and the possibility of composing package solutions to fit different needs at different levels. Given the complexity of the choices we are faced with, this combination of mechanisms may be the only 
feasible way to proceed. In addition, each of these structures can potentially check and place limits on the others. Not everyone will be satisfied, but this is in any case an impossible goal.

This means that achieving sustainability may well depend on insuring the proper functioning of all four of these mechanisms. They share the requirement for genuinely democratic national and international structures that allow for the organization of civil society and the free flow of knowledge. These are needed to protect the integrity of choices by insuring that the information upon which they are made is the most accurate possible and that choices are not forced through by a few powerful actors. This means, for example, that individual corporations cannot be allowed to control production: harnessing the power of competition in the market requires multiple producers. It also means that at either the national or local level, communities must retain the ability and political space to compose the solutions that best reflect their package of needs and preferred trade-offs among preferences.

\section{References}

AquaBounty. (2013) AquaBounty cleared to produce salmon eggs in Canada for commercial purposes. Retrieved March $2^{\text {nd }} 2014$ from: http://www.aquabounty.com/documents/press/ 2013/20131125.pdf

Arengo, E., Diaz, E., Ridler, N. \& Hersoug, B. (2010) State of information on social impacts of salmon farming. A report by the technical working group of the salmon aquaculture dialogue. World Wide Fund for Nature. Retrieved January $23^{\text {rd }} 2014$ from:

http://assets.worldwildlife.org/publications/196/files/original/ State_of_Information_on_Social_Impacts_of_Salmon_Farming_SalmonL.pdf?1344876856.

Barbier, E. (1987) The concept of sustainable development. Environmental Conservation 14 (2), $101-110$.

Barton, J. (1997) Environment, sustainability and regulation in commercial aquaculture: The case of Chilean salmonid production. Geoforum 28 (3-4), 313-328.

Barton, J. \& Fløysand, A. (2010) The political ecology of chilean salmon aquaculture, 1982-2010: A trajectory from economic development to global sustainability. Global Environmental Change 20, 739-752.

Buschmann, A.H., Riquelme, V.A. Hernandez-Gonzalez, M.C., Varela, D., Jimenez, J.E., Henriquez, L.A., Vergara, P.A, Guinez, R. \& Filun. L. (2006) A review of the impacts of salmonid farming on marine coastal ecosystems in the Southeast Pacific. ICES Journal of Marine Science 63, 1338-1345.

Bustos, B. (2010) Geographies of knowledge production in a neoliberal setting: The case of Los Lagos Region, Chile (Ph.D.-dissertation, The Graduate School of Syracuse University).

Center for Food Security and Public Health \& Institute for International Cooperation in Animal Biologics. (2010) Infectious Salmon Anemia/Hemorrhagic Kidney Syndrome. Retrieved January $18^{\text {th }} 2014$ from: http://www.cfsph.iastate.edu/DiseaseInfo/disease.php?name=infectioussalmon-anemia\&lang=en

Dryzek, J.S., Downes, D., Hunold, C., Scholsberg, D. \& Hernes, H.K. (2003) Green States and Social Movements: Environmentalism in the United States, United Kingdom and Norway. Oxford: Oxford University Press. 
ECOCEANOS. (2013) Mapuches communities oppose expansion of salmon farming in southern Chile. Retrieved January $23^{\text {rd }} 2014$ from:

http://www.ecoceanos.cl/index.php?option=com_content\&task=view\&id=12461

Ellingsen, H., Olaussen, J.O. \& Utne, I.B. (2009) Environmental analysis of the Norwegian fishery and aquaculture industry: A preliminary study focusing on farmed salmon. Marine Policy 33 (3), 479-488.

Evans, D. (2006) Gyrodactylus salaries, Monogean salmon parasite. Retrieved January $15^{\text {th }} 2014$ from: http://www.habitas.org.uk/invasive/species.asp?item $=50006$

FAO (Food and Agriculture Organization of the United Nations). (2012) The state of world fisheries and aquaculture. Rome: FAO.

FAO (Food and Agriculture Organization of the United Nations). (2014a) Aquaculture. Retrieved January $20^{\text {th }} 2014$ from: http://www.fao.org/fishery/aquaculture/en

FAO (Food and Agriculture Organization of the United Nations). (2014b) Global aquaculture production. Retrieved January $20^{\text {th }} 2014$ from: http://www.fao.org/fishery/statistics/globalaquaculture-production/en

Fish and Information Services. (2013) Marine Harvest, WWF call for proper GM salmon labelling. Retrieved March $2^{\text {nd }} 2014$ from: http://www.fis.com/fis/worldnews/worldnews.asp?monthyear \&day $=4 \& \mathrm{id}=65135 \& \mathrm{l}=\mathrm{e} \&$ special $\& \mathrm{ndb}=1+\operatorname{target} \% 3 \mathrm{D}$

Fis eridirektoratet. (2013) Oppdaterte rømmingstall. Retrieved January $23^{\text {rd }} 2014$ from: http:// www.fiskeridir.no/akvakultur/aktuelt/2009/1209/oppdaterte-roemmingstall

Fis eridirektoratet (2014) Lønnsomhet. Retrieved January $23^{\text {rd }} 2014$ from: http://www.fiskeridir.no/fiskeridir/statistikk/akvakultur/loennsomhet

Fisheries and Oceans Canada. (2013) Summary of the environmental and indirect human health risk assessment of AquAdvantage ${ }^{\infty}$ salmon. Retrieved March $2^{\text {nd }} 2014$ from: http://www.dfompo.gc.ca/csas-sccs/Publications/ScR-RS/2013/2013_023-eng.pdf

Fleming, I.A, Hindar, K. Mjølnerød, I.B., Jonsson, B., Balstad, T. \& Lamberg, A. (2000) Lifetime success and interactions of farm salmon invading a native population. Proceedings of the Royal Society 267 (1452/August 7), 1517-1523.

Forrest, C. (2006). Integrated coastal zone management: A critical overview. WMU Journal of Maritime Affairs 5 (2), 207-222.

Gelcich, S., Hughes, T.P., Olsson, P., Folke, C., Defeo, O., Fernandez, M., Foale, S., Gunderson, L.H., Rodriquez-Sickert, C., Scheffer, M., Steneck, R.S. \& Castilla, J.C. (2010) Navigating transformations in governance of Chilean marine coastal resources. PNAS 107 (39), 16794-16799.

Giddings, B., Hopwood, B. \& O’Brien, G. (2002) Environment, economy and society: Fitting them together into sustainable development. Sustainable Development, 10, 187-196.

Hamilton, H. (2013) Aquaculture: Methods for assessing sustainability. Paper presented at the workshop «The Values of Aquaculture: What is the Price of Growth?» Trondheim: Norway.

Hersoug, B. \& Johnsen, J.P. (2012) 12 teser om kystsoneforvaltning og norsk fiskeoppdrett. In Kampen om plass på kysten: Interesser og utviklingstrekk $i$ kystsoneplanleggingen, eds. B. Hersoug \& J.P. Johnsen, pp. 261-181. Oslo: Universitetsforlaget.

International Institute for Sustainable Development. (2013) What is sustainable development? Retrieved March $3^{\text {rd }} 2014$ from: http://www.iisd.org/sd

Iriarte, J.L., Gonzales, H.E. \& Nahuelhual, L. (2010) Patagonian fjord ecosystems in Southern Chile as a highly vulnerable region: Problems and needs. Ambio 30, 463-466.

Jonsson, B. \& Jonsson, N. (2006) Cultured Atlantic salmon in nature: A review of their ecology and interaction with wild fish. ICES Journal of Marine Science 63, 1162-1181.

Krkošek, M., Connors, B.M., Morton, A., Lewis, M.A., Dill, L.M. \& Hilborn, R. (2011) Effects of parasites from salmon farms on productivity of wild salmon. Proceedings of the National Academy of Science 108 (August 30), 14700-14704. 
Lélé, S.M. (1991) Sustainable development: A critical review. World Development 19 (6), 607-621. León-Muñoz, J., Tecklin, D., Farías, A. \& Díaz, S. (2007) Salmon farming in the lakes of Southern Chile - Valdivian ecoregion: History, tendencies and environmental impacts. WWF/Chilean Society of Limnology.

Liu, Y., Olaussen, J.O. \& Skonhoft, A. (2011) Wild and farmed salmon in Norway - A review. Marine Policy 35, 413-418.

Lozano, R. (2008) Envisioning sustainability three-dimensionally. Journal of Cleaner Production $16,1838-1845$.

Mapuche Documentation Center. (2007) Open letter: To all political and corporate institutions of Norway, Finland and Switzerland. Mapuche International Link News. Retrieved January $23^{\text {rd }}$ 2014 from: http://www.mapuche-nation.org/english/html/news/n-109.htm.

Marine Harvest. (2012) Salmon farming industry handbook 2012. Retrieved January $20^{\text {th }} 2014$

from: http://www.marineharvest.com/PageFiles/1296/

2012\%20Salmon\%20Handbook\%2018.juli_h\%C3\%B8y\%20tl.pdf

Ma ine Harvest. (2011) How to feed the world. Retrieved March $3^{\text {rd }} 2014$ from: http://www.marineharvest.com/no/CorporateResponsibility/Salmon-feed/How-to-feed-the-world/

Marine Harvest. (2009) Sustainability report. Oslo: Marine Harvest ASA.

MFCA (Ministry of Fisheries and Coastal Affairs), Government of Norway. (2013) Facts about fisheries and aquaculture. Retrieved March $27^{\text {th }} 2014$ from: http://www.regjeringen.no/upload/ FKD/Vedlegg/Rapporter/2013/L-0553E_WEBHele.pdf

Millennium Ecosystem Assessment. (2005) Ecosystems and human well-being: Synthesis. Washington, D.C: World Resources Institute/Island Press.

NOAA. (2014) Climate variability and marine fisheries: Collapse of anchovy fisheries and the expansion of sardines in upwelling regions. NOAA, PFEL Climate \& Marine Fisheries. Retrieved January $19^{\text {th }} 2014$ from: http://www.pfeg.noaa.gov/research/climatemarine/cmffish/ cmffishery4.html

Norman, W. \& MacDonald, C. (2004) Getting to the bottom of the «triple bottom line» Business Ethic Quarterly, 14 (2), 243-262.

Norwegian Seafood Federation \& Norwegian Seafood Council. (2011) Aquaculture in Norway. Retrieved March $27^{\text {th }} 2014$ from: http://fhl.no/download-factsheets-and-other-publications/ \#brosj

Norwegian Seafood Federation \& Norwegian Seafood Council. (2010) 20 questions and answers about farmed Norwegian salmon. Retrieved March $2^{\text {nd }} 2014$ from: http://fhl.no/wp-content/ uploads/importedfiles/QA_salmon.pdf

Norwegian Ministry of Trade and Industy. (2012) Destination Norway: National strategy for the tourist industry. National Ministry of Trade and Industry, 10 April 2012. Retrieved March $3^{\text {rd }}$ 2014 from: http://www.regjeringen.no/pages/37646196/Lenke_til_strategien-engelsk.pdt

Olsen, Y. (2011) Resources for fish feed in future mariculture. Aquaculture Environment Interactions $1,187-200$.

Ostrom, E. (2007) A diagnostic approach for going beyond panaceas. PNAS 104 (39), 1528115187.

Phyne, J. (2010) A comparative political economy of rural capitalism: Salmon aquaculture in Norway, Chile and Ireland. Acta Sociologia 53 (2), 160-180.

Pinto, F. \& Furce G. (2006) Salmon piranha style: Feed conversion efficiency in the Chilean salmon farming industry. Retrieved January $12^{\text {th }} 2014$ from: http://www.farmedanddangerous.org/wpcontent/uploads/2011/01/Piranha_TC_ENG_PDF.pdf

Putnam, R.D. (1993) Making Democracy Work: Civic Traditions in Modern Italy. Princeton, New Jersey: Princeton University Press. 
Soto, D., Hara, F. \& Moreno, C. (2001) Escaped salmon in the inner seas, southern Chile: Facing ecological and social conflicts. Ecological Applications 11 (6), 1750-1762.

SSB (Statistisk sentralbyrå). (2014) Aquaculture: Table: 07633: Fish farming of salmon and rainbow trout. Number of workers and labour input, by type of production. Retrieved January $23^{\text {rd }} 2014$ from: https://www.ssb.no/en/jord-skog-jakt-og-fiskeri

Tacon, A.G.J., Hasan, M.R. \& Metian, M. (2011) Demand and supply of feed ingredients for farmed fish and crustaceans: Trends and prospects (FAO Technical Papers 564). Rome: FAO.

Thorstad, E.B., Fleming, I.A., McGinnity, P., Soto, D., Wennevik, V. \& Whoriskey, F. (2008) Incidence and impacts of escaped farmed Atlantic salmon Salmo Salar in nature. N.c.: Norwegian Institute for Nature Research/World Wildlife Fund.

Tiller, R.G., Brekken, T. \& Bailey, J.L. (2012) Norwegian aquaculture and integrated coastal zone management (ICZN): Simmering conflicts and competing claims. Marine Policy, 36 (5), $1086-$ 1095.

Tiller, R.G., Ellis, J., Moe, E., Richards, R., Salgado, H. \& Strand, H. (2013) Assessing stakeholder adaptive capacity to salomon aquaculture in Norway. Paper presented at the International Studies Association Annual Meeting, San Francisco, April 2013.

Wa mart. (2014) Walmart: Sustainable Seafood. Retrieved January $24^{\text {th }} 2014$ from: http://corporate.walmart.com/global-responsibility/environment-sustainability/sustainable-seafood

Var derbilt University. (2014) What is sustainability? Retrieved March $2^{\text {nd }} 2014$ from: http:// www.vanderbilt.edu/sustainvu/who-we-are/what-is-sustainability/

Wh ole Foods. (2014) Whole foods: Seafood sustainability. Retrieved January $14^{\text {th }} 2014$ from: http: (www.wholefoodsmarket.com/mission-values/seafood-sustainability

Windsor, M.L., Hutchenson, P., Hansen, L.P. \& Redden, D.G. (2012) Atlantic salmon at sea. Findings from recent research and the strategic implications for management. Edinburgh: NASCO. NASCO document CNL(12)60. Retrieved March 27 2014 from: http:// www.nasco.int/pdf/reports_other/Salmon_at_sea.pdf

World Commission on Environment and Development (WECD). (1987) Our Common Future: Report of the World Commission on Environment and Development. Retrieved March $2^{\text {nd }} 2014$ from: http://www.un-documents.net/our-common-future.pdt

World Health Organization (WHO). (2014) 20 questions on genetically modified food. Retrieved March $2^{\text {nd }} 2014$ from: http://www.who.int/foodsafety/publications/biotech/20questions/en/ 